\title{
"Very busy": daily reorganization of mothers to care of children with Congenital Zika Syndrome
}

\author{
"Bem corrido": reorganização cotidiana das mães para cuidar \\ de crianças com Síndrome Congênita pelo Zika \\ "Muy ocupada": reorganización diaria de las madres para \\ cuidar a niños con Síndrome Congénito del Zika
}

\author{
Paulo Roberto Lima Falcão do Vale ${ }^{a, b}$ \\ Deisyane Vitória Alves ${ }^{\mathrm{b}}$ \\ Evanilda Souza de Santana Carvalho ${ }^{b}$
}

\section{How to cite this article:}

Vale PRLF, Alves DV, Carvalho ESS. "Very busy": daily reorganization of mothers to care of children with Congenital Zika Syndrome. Rev Gaúcha Enferm. 2020;41:e20190301. doi: https://doi. org/10.1590/1983-1447.2020.20190301
- Universidade Federal do Recôncavo da Bahia (UFRB). Centro de Ciências da Saúde. Santo Antônio de Jesus, Bahia, Brasil.

${ }^{b}$ Universidade Estadual de Feira de Santana (UEFS) Departamento de Saúde. Programa de PósGraduação em Saúde Coletiva. Feira de Santana, Bahia, Brasil.

\section{ABSTRACT}

Objective: To understand the experiences and care practices of mothers of children with congenital Zika syndrome.

Methods: A qualitative study with collection held in Feira de Santana - Bahia, between September and November 2017, from indepth interviews and Story-Drawing with 11 family members of children, using thematic content analysis.

Results: Mothers take care from experiences with health professionals and groups of mothers. They reorganize themselves in order to optimize time, streamline domestic activities, teach family members, and navigate care spaces. They experience the routine organizing the home, taking care of the children and, specifically, the child with syndrome, referring to: bedtime; giving a shower; changing diapers; feeding; playing; and, stimulating, actions mediated by intense crying and environmental preparation.

Conclusion: The experiences are unique and exceptional, conforming the social representation of the mothers as a group, the "mothers of micro", an aspect that differs from other experiences.

Keywords: Microcephaly. Zika virus. Congenital abnormalities. Disabled children. Mother-child relations.

\section{RESUMO}

Objetivo: Compreender as experiências e práticas de cuidado das mães de crianças com Síndrome Congênita pelo Zika.

Métodos: Estudo qualitativo com coleta realizada em Feira de Santana - Bahia, entre setembro e novembro de 2017, a partir de entrevistas em profundidade e Desenho Estória-Tema com 11 familiares das crianças, utilizando a análise de conteúdo temática.

Resultados: As mães cuidam a partir das experiências com profissionais de saúde e grupos de mães. Elas se reorganizam para otimizar 0 tempo, agilizar as atividades domésticas, ensinar aos familiares e percorrer os espaços de cuidado. Experienciam a rotina organizando o domicílio, cuidando dos filhos e, especificamente, da criança com síndrome, referentes à: ninar; dar banho; trocar fraldas; alimentar; brincar; e, estimular, ações mediadas por choro intenso e preparação do ambiente.

Conclusão: As experiências são únicas e singulares, conformando a representação social das mães enquanto grupo, as "mães de micro", aspecto que difere de outras experiências.

Palavras-chave: Microcefalia. Zika vírus. Anormalidades congênitas. Crianças com deficiência. Relações mãe-filho.

\section{RESUMEN}

Objetivo: Comprender las experiencias y prácticas de atención de las madres de niños con síndrome congénito por Zika.

Métodos: Estudio cualitativo con recolección de datos realizada en Feira de Santana - Bahía, entre septiembre y noviembre de 2017, a partir de entrevistas en profundidad y Story-Drawing con 11 familiares de niños, utilizando análisis de contenido temático.

Resultados: Las madres cuidan a partir de las experiencias con profesionales de la salud y grupos de madres. Se reorganizan para optimizar el tiempo, agilizar las actividades domésticas, enseñar a los integrantes de la familia y navegar por los espacios de atención. Experimentan la rutina organizando el hogar, cuidando a los niños y, específicamente, al niño con síndrome, refiriéndose a: la hora de acostarse; el baño; el cambio de pañales; la comida, los juegos y la estimulación, acciones mediadas por llanto intenso y preparación ambiental.

Conclusión: Las experiencias son únicas y excepcionales, conformando así la representación social de las madres como grupo, las "madres de micro", un aspecto que difiere de otras experiencias.

Palabras clave: Microcefalia. Virus Zika. Anomalías congénitas. Niños con discapacidad. Relaciones madre-hijo. 


\section{口INTRODUCTION}

In 2016, from the Zika virus (ZIKV) epidemic in Brazil, the direct causal relation between the virus and microcephaly was highlighted ${ }^{(1)}$. Between September and December 2015,1,608 cases of microcephaly were reported, a nine-fold increase compared to those reported between 2000 and $2014^{(2)}$. Subsequent studies identified more intense repercussions justifying the use of the term congenital Zika virus syndrome (CZVS) determined by craniofacial disproportion, spasticity, seizures, irritability, muscle contractures, eye and hearing abnormalities, and brain abnormalities identified by neuroimaging ${ }^{(3)}$. The prevalence of CZVS declines from 2017, but still remains high; between January and April 2019 a mean of 124 cases per month were reported. From the beginning of the notification of cases in the country (08/11/2015) to $11 / 05 / 2019$, there were 17,642 reported cases and, among those concluded, only $46.6 \%$ were discarded ${ }^{(4)}$.

Singular experiences emerged from women who wanted to be mothers and produce a perfect child, but received an inaccurate diagnosis, with a cause little known by science at the time and with a poorly defined prognosis, variable for each child, generating insecurity, anguish and longing for the children's family, particularly for mothers, because they look after their children more intensively and directly ${ }^{(5)}$.

Mothers of children with CZVS live with lower psychological quality of life rates, high levels of anxiety ${ }^{(6)}$, depression and care overload, results that may be associated with low family income ${ }^{(6-7)}$, to divorce or separation from partner, difficulties in accessing treatment, confronting discriminatory comments ${ }^{(5)}$, social isolation and abdication of personal and professional projects ${ }^{(7-8)}$. In addition to these repercussions, it is known that $74 \%$ of these mothers declare themselves non-white, $48 \%$ completed high school, $68 \%$ live in precarious conditions and $75 \%$ were dismissed or resigned from employment ${ }^{(9)}$.

Despite knowing the characterization of mothers and the repercussions of CZVS in the mother's health-disease process, no studies were found that investigated maternal child care as a central element of analysis. For example, ethnography conducted with the mothers of the city of Recife, Pernambuco, investigated their experiences with the child with microcephaly from the anthropological approach of daily life ${ }^{(7)}$, another study focused in knowing the impact of CZVS on families. Therefore, the knowledge gap to be filled by this study conforms.

This study contributes to the modeling of the work processes of the nursing staff and other health professionals after understanding the care attitudes of mothers of children with CZVS, as these are little known actions that required longitudinal care. For such relevance we seek to answer the following guiding question: What are the experiences and care practices of mothers of children with congenital syndrome associated with Zika virus? This study aims to understand the experiences and care practices of mothers of children with congenital syndrome associated with Zika virus.

\section{METHODS}

A qualitative study from in-depth interviews and Story-Theme Design using thematic content analysis. It was held at the Association of Parents and Friends of the Exceptional of Feira de Santana - Bahia, which offers care to people with intellectual and physical disabilities. Eleven family members of eligible children with CZVS participated according to following the inclusion criteria: being a member of the family system of the child with CZVS, condition confirmed orally by the study participant; and being responsible for the child with CZVS during contact with the researcher. Given the above, the study has no exclusion criteria.

The number of participants was established based on the theoretical-empirical saturation criterion of the data ${ }^{(10)}$. Data collection took place between October and November 2017; data were obtained from the application of story-theme drawings, in-depth interviews and field diary.

All participants signed the Free and Informed Consent Form, approved, as well as the entire study, by the University's Ethics and Research Committee through Opinion No.2,178,649 on July $19^{\text {th }}, 2017$.

The participants were offered a blank sheet of paper, colored pencils and a pen, and then asked to draw a free drawing, so that there was a first recognition of the materials and stimulation to make the drawing. Then the participants were encouraged to draw something that came to their mind from the statement "draw something that represents living with the child with CZVS". Upon completion of the drawings they were asked to look at the drawings and make a story with a beginning, middle and end, and then they were asked to read the story and give it a title. Each mother then freely chose the fictitious name attributed to the authorship of her drawing and the subsequent interview to ensure anonymity of the true identity of the participants. D-E is a projective technique that facilitates the expression of subjectivity and allows investigation by expanding the individuals' forms of expression (11).

Then open interviews were recorded and transcribed in full by the interviewer himself; their duration ranged from 21 to 56 minutes. Data collection took place in a private setting with the presence of the participant and the lead author, with master's degree. The material from the interviews was subjected to content analysis, performed in six stages: reading and rereading data, creating codes for important topics, 
grouping codes, building a mind map identifying relations between the themes, naming the themes and producing the synthesis of the analysis ${ }^{(12)}$. The analysis of the D-E followed these steps: 1 - Systematic observation of the drawings; 2 - Selection of the drawings by similarities whether graphic and/or thematic; 3 - Floating reading of the thematic units of the stories; 4 - Clipping and categorization; 5 - Analysis and interpretation of the thematic contents grouped by categories; 6 - Analysis and interpretation of the drawings through graphics ${ }^{(11)}$.

The authors then confronted the thematic nuclei arising from content analysis and the D-E, constituting three categories presented in the results section: "Learning to take care of the child", "Rearranging the daily life to take care of the child" and "Providing care and evaluating its results". The themes emerged were discussed and evaluated by the authors, consisting of three PhD nurses and two Master nurses.

\section{口ESULTS}

Of the eleven participants, ten were mothers and a sister of children with CZVS, aged between 18 and 42 years, with a mean of 27 years old. The children were between one year and five months old and two years and six months old, with a mean of one year and nine months old. Maria, sister of one of the children, provides all the care that the mothers perform, her mother works eight hours a day and takes care of the child at night, a practice that justifies the inclusion of Maria in this study. The child with CZVS was the first child of four families in this study, two children had one brother each, one lived with two sisters, and another three families had four children in total. The siblings were between 03 and 18 years old, with a mean age of 7.66 years old.

Regarding marital status, one participant self-defined as separated, because the father did not recognize his daughter with CZVS, attributed the cause of the syndrome to the mother and left the home, four lived in stable union and six were single, one of them assumed this state after the child's arrival, not reporting the motivation for it. Six were housewives, three farmers, one a college student, and another a grocery clerk. Six women were Catholic, two evangelical, one Candomblecist, and two claimed to have no religion. Six respondents completed high school, ten were unemployed, with income from social programs and sporadic jobs, totaling a family income of less than half the minimum wage.

\section{Learning to take care of the child}

Initially, the repercussions of the CZVS epidemic on social networks and television helped the family members to know about the syndrome, which eventually resulted in the search for more and better knowledge. This information was accessed by caregivers through conversations in waiting rooms of health facilities and participation in the groups of mothers of children with CZVS.

\section{Learning from professionals and groups of mothers about CZVS and childcare}

Disabled care facilities and rehabilitation services were the settings of the care network where mothers found information to meet their children needs.

As CZVS was little known even by the professionals themselves, the information was gradually accessed, as children evolved with signs, symptoms of complications and disabilities perceived by their mothers, requiring them to be vigilant due to the unpredictability of acute events that put their child's life at risk.

[...] / met Adriana, mother of Lorena [a child with microcephaly]. Then she tried and began to explain to me how to care, what the child felt, if she had seizures, choking (Ana, mother).

We learned about microcephaly in the hard way. The first things that happened like this were in the maternity ward, [...] explaining us (Maria, sister).

Although some of the mothers received guidance at the maternity ward, saying "the hard way" means complexity of the learning process, with intense energy expenditure, determination and little help from others.

In addition to the knowledge shared in mothers' social groups, as the participants also knew and learned to perform early stimulation with health professionals in the services attended by the child.

The service there is this type, they enable the family to take care of the child, at Sarah it's that way. At Sarah, APAE, in the Children's Hospital (Drica, mother).

We have a group of mothers who teach us how to stay close to the children (Leticia, mother).

During the interview, Leticia demonstrated the competence to care, laid the child on the carpet, close to the toys and objects that help stimulation, then proceeded with stimulation exercises for neck and trunk muscles.

In the group [of mothers], it was taught how to make modeling dough with wheat flour and liquid dye. Then the child can play and eat too. We help each other (Bianca, mother). 
For Bianca, the social group means a space for mutual help, learning and coping with difficulties that mothers experience and hope to overcome.

\section{Rearranging the daily life to take care of the child}

Mothers experience a routine with many activities, listing the tasks of the home setting, doing chores with children without CZVS and caring for the treatment and rehabilitation of children with CZVS.

\section{Increasing the burden of housework and traversing the care spaces}

Paula and Bianca use the expression "very busy" and the term "busy" to characterize the reorganization of daily life, respectively. It is the increase of the domestic load plus the responsibility of accompanying the child during the paths taken in search of care, as evidenced by the reports:

Very busy, because I have to take care of her, take care of the house, take care of the other (son) who goes to school, take care of the other who will come from school [...] (Paula, mother).

It's busiernow, because I go out all week, Monday, Wednesday and Friday, so Tuesday and Thursday I see what I need to do at home [...] (Bianca, mother).

The word "caring" repeatedly expressed by Paula indicates doing, the act of caring for the child, the home setting and other family members, requiring efforts, commitments and dedication. In addition, the term "very busy" emanates the significance of a full day of activities performed by the mother, thus represents ellipses of events that need to be performed within 24 hours for the well-being of all, with no time to rest.

Those mothers who have other school-age children still mobilize to meet their needs before they go to school and after their return, so they prepare the food to eat before, during and after school, clean their uniforms, organize school materials and follow up on school activities at home. In addition, when returning from school, the child may require attention, dialog and other tasks related to school tasks from the mother.

The mothers clean the house, wash the household utensils and the clothes of the family members, according to Ana. Associated with this, they are responsible for the preparation of all family meals, with specificities in the food of each member.
I clean the house, do the dishes, do the laundry, cook (Ana, mother).

Teaching family members and dedicating themselves exclusively to taking care of the child

Being with someone who maintains a relation of bond and trust, and availability for child care is a concern for Brenda. She thinks about the possibility of someone replacing her when absent, so she shares her knowledge and practices with the family network to ensure continuity of care:

[...] I say I'm not made of iron, one day l'll get sick and if I get sick how will be Ramon if no one can give him water? Now I'm teaching and they are learning (Bianca, mother).

The mother's routine is changed due to the longer time spent traveling to seek treatment for the child, as evidenced in Drica's theme-story design. Mothers often move from home to child rehabilitation/stimulation centers, this statement can be confirmed by the analysis of D-E (Figure 1) prepared by Drica, entitled "Microcephaly is not the end, it is the beginning of an endless love".

On the lower right side of the drawing she represents her role of performing stimulation in Lavinia, the child is lying on the carpet, near several toys that help stimulation. At this moment some mothers narrated and stimulated the child in front of the researcher, demonstrating all the practice they had mastered.

The accumulation of household chores plus the responsibility of routinely attending child rehabilitation/stimulation centers requires their exclusive dedication away from other socialization, leisure and self-care activities.

\section{Optimizing time and speeding up housework}

Time is an important aspect of care, which mothers seek to save on other tasks to devote more time to their children, as well as speed up their chores while children sleep or when they have the help of another family member.

Some mothers choose to cook large quantities of food at once and freeze for later consumption. By pre-arranging family meals, they avoid spending several hours a day preparing food to extend child care.

[...] the food I already leave in the fridge, when we get tired, I just need to boil it. Like, during noon and night is more soup, I already cook and leave it in the freezer so l just need to boil it (Bianca, mother). 


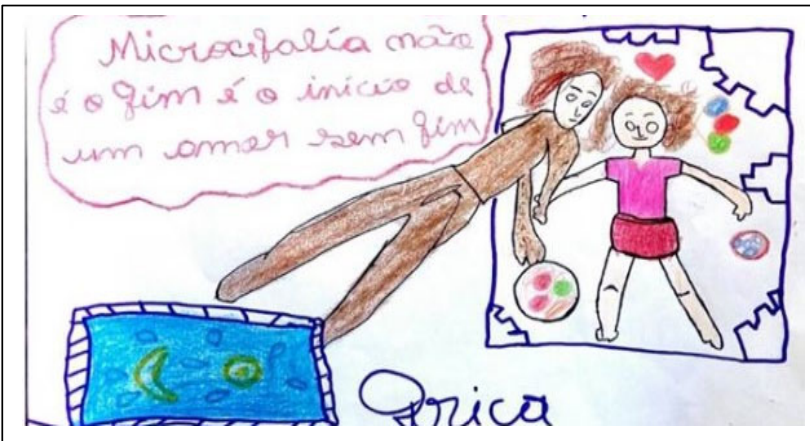

\section{MICROCEPHALY IS NOT THE END}

My life today comes down to taking care of Lavinia and the house, but the priority is my daughter. Also, because the treatment is always in Salvador or Feira [de Santana] and there isn't much time for other things. This is me doing early stimulation in Lavinia.

Figure 1 - Microcephaly is not the end, it is the beginning of an endless love (Drica, 36 years old, mother of Lavinia, 20 months old, diagnosed with CZVS in the fourth month of gestation)

The daily care is all that, being with him always. If he is on the carpet I have to be there, only when he sleeps, I will do something [...] (Carla, mother).

Both food preparation and home setting organization can be interrupted by the momentary and unexpected behavior of the child with CZVS, considered a priority. For Carla, care is something continuous and unique, it is "everything", it is "being together" at all times, with no rest breaks in her daily life; therefore, the child's sleep time or the presence of another family member, as reported by Leticia, is appropriate for the organization and cleaning of the living environment, necessary for all who reside there.

When I want to tidy up the house, I ask my mother to hold the child (Leticia, mother).

If I have someone to look after [the child with CZVS] I do the housework (Ana, mother).

For Leticia and Ana, the task of organizing the home setting is conditional on the existence of another person who can "take care" of the child with microcephaly while performing a certain activity.

\section{Providing care and evaluating its results}

Sanitizing, lulling, feeding, playing and stimulating are some of the care practiced by mothers and are adjusted based on their own assessment.

\section{Caring for the child amid intense crying}

Measures usually adopted with children in general such as bathing; changing diapers and feeding are added to a different way of playing, one that incorporates the knowledge of the professionals who guide them to "stimulate" the child to develop both motor and cognitive skills preventing damage that results in disability. In addition, the child's crying occupies the mother for hours cradling him/her in an attempt to calm him/her down and make him/her sleep.

She stays all day in my lap, moving from side to side, going out of it, being quite for a while then coming back again, getting some sleep, waking up crying (Maria, sister).

The practice of lullaby is referred to as a physically exhausting activity that only ends when the child's crying ends or when the child falls asleep, so the mothers go through various spaces indoors, with the child in their arms, almost always swinging the child.

Maria explains that bedtime is the only effective way to reduce the irritability and frequency of crying, consequently, children can fall asleep, but it is not a long sleep, i.e., being with the child in her arms, swinging, represents low intensity of crying, although for a short time.

With this practice, the mothers aim to favor an uninterrupted night's sleep. Although it is strenuous and tiring for them, when assessing the side effects on children's behavior they find it safer not to offer them medications and prioritize lullaby, as Carla reports:

We do not always give the sleeping medicine, because the other day makes him stressed, tired, so we prefer to make a way for him to sleep by himself, lulling (Carla, mother).

Therefore, the choice for family care does not favor the mother's health, rest or expansion of sleep time, but rather the best health conditions of the child.

During the interviews, the mothers showed physical discomfort and often asked the researcher to help them by 
holding the child while they performed neck, spine, hands, feet, lower and upper limb stretching exercises while being interviewed and the child was "held" by the researcher.

\section{Assessing the child's swallowing ability}

The feeding of children with microcephaly may be liquid, pasty and semi-solid, cited by mothers as porridges, baby food of fruits and vegetables and mashed vegetables. Mothers aim for a better development in their child's swallowing capacity, so they understand that they can evaluate their children's development from the acceptance of the offered food, aiming to evolve towards the acceptance of semisolids.

[...] learned to suckle the baby bottle, so already takes porridge. After the treatment with the phono [speech therapist] she eats a little beat in the blender and now it's crumpled up. (Paula, mother).

It is also possible to perceive the attribution given to speech therapy by the progress in the development of Paula's daughter, there is a greater capacity for swallowing progressing from liquid to semisolid feeding.

Ana's drawing illustrates feeding as one of the main care actions, in the scene she is ready to offer the bottle to her daughter and writes her story titled "Care", as shown in Figure 2.

\section{Preparing a setting and doing stimulation}

Mothers intensify efforts and seek greater resources for better child development, such as building a space reserved for play and stimulation of children with microcephaly, similar to those in rehabilitation/stimulation centers.

In some settings of the house, the family distributes comfortable tatamis or mats, provides various types of toys and set aside that space for the stimulation exercises and family play with the child.

[...] we sit on the mat, l even bought a mat, lots of toys to call the attention (Brenda, mother).
We have a tatami with her little things, we go to the floor and play with her (Maria, sister).

Although they use the same space, some mothers cite playing and stimulation as different activities. Playing refers to any kind of action that causes the child to smile, using balls, dolls and other toys that make sounds. Playing can be the act of tickling your fingers in the child's axillary area to smile.

I do what the physiotherapists teach, stretch their arms, crawl, put their arms around and put their little legs together, [...] so she can learn to move (Ana, mother).

Stimulating refers to the planned movement of the body, reproducing the repetition of practices that are done in rehabilitation/stimulation centers to reach the stages of stretching, "moving", crawling and lifting. Early stimulation is commonly conducted by the mothers who were qualified by the health service professionals so, before the act of stimulating, the mothers experienced the learning process with physiotherapists and occupational therapists, especially.

Despite the difficulties related to "very busy" experiences, childcare reserves for mothers the accumulation of scientific knowledge, the construction of new knowledge and practices, as well as the expansion of interpersonal relationships in the "mothers of micro" group.

\section{DISCUSSION}

The experience and care practices of mothers of children with CZVS are unique, exceptional and differ from the experience of mothers of children with other congenital anomalies, mainly due to the condition of collective social individual, named as "mothers of micro"(7).

Although children with microcephaly and other anomalies already existed, the phenomenon of CZVS promoted the visibility of the experience of these families, highlighting the experience of a collective eager to learn about child-specific care. Therefore, mothers of children with CZVS formed a social

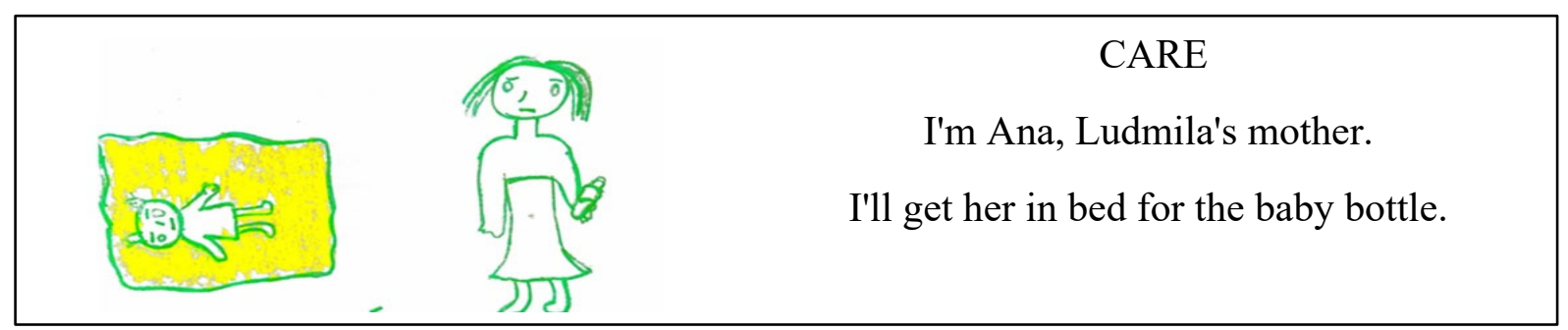

Figure 2 - Care (Ana, 23 years old, mother of Ludmila, 1 year and 6 months old. CZVS diagnosis at three months of age) 
group of people with common goals, mutual responsibility, and shared experiences.

We highlight the scarcity of studies on the experience of mothers of children with CZVS (13). However, in analogy with mothers of children with cerebral palsy, we perceive limits in their consolidation as a social group, since it is a disease with low prevalence ${ }^{(14)}$. Therefore, the organization of individual mothers results in experiences of mothers with unequal health needs, with experiences among family members, poorly shared with other mothers or groups ${ }^{(14)}$ and with professionals who give little dialogued orientations, restricting the diversity of learning and, consequently, limiting care and demanding the creativity of mothers for their practices.

Mothers received inaccurate diagnoses at the time of CZVS discovery, as well as poorly defined prognoses ${ }^{(7)}$, variables according to the biological response of the child and the care provided by the families, which contribute to the exceptionality of this experience when compared to other congenital anomalies. This uncertainty enhances the desire of mothers of children with CZVS to create, reproduce and adhere to the care to improve their children's development and, at the same time, seek to reduce family self-blame, so the mothers'learning process took place more intense and participatory, enabling the accumulation and care practices in the family, revealed by an open attitude to assimilation and dissemination of new knowledge.

Mothers seek to meet gender expectations, which include partner satisfaction, the organization and hygiene of the home environment, as well as the care and education of their children ${ }^{(7,15)}$, resulting in physical tiredness and depression ${ }^{(15)}$.

The CZVS phenomenon favored the discrediting of the woman in the social role of procreation, conceiving an imperfect child, embarrassing her to attend social spaces and restricting her in the domestic sphere ${ }^{(16)}$. The place of female domination imprisons and feeds her character of submission, limiting her ability to play multiple roles between men and women, without empowerment or social recognition between them.

In this context, mothers of children with CZVS have abdicated their professional careers and family financial provision that, for now, needed to be discontinued due to the accumulation of tasks. Restricting herself to the home setting seems to be a consequence of CZVS for this woman, as there is no more time available for leisure, building new friendships and activities of her interest ${ }^{(15)}$, because children require more care. This naturalness that family care is assumed by women generates stress, decreases the psychological dimension of quality of life, raises anxiety levels ${ }^{(6)}$ and becomes ill. This social role is nurtured by significant people from the social group close to women, who, in turn, largely assume these socially constructed behaviors and care. In addition to structural machismo, the prevalence of CZVS reaches higher rates in the Northeast region (71\%)(2) and in poor people in Brazil. These are people who face difficulties in accessing health services, live in precarious sanitation and housing situations, or live in places with discontinued supply of drinking water, forcing stockpiling that favors the proliferation of carriers ${ }^{(16)}$.

For each phase of child development, the child has different nutritional demands and changes in food supply accompany the advances in the stages of maturation of swallowing capacity. Therefore, family surveillance is valid in identifying the type of food your child can eat, requiring direct contact with each meal, ensuring a reliable assessment of progress ${ }^{(17)}$.

Therefore, the participation of the health professionals in the qualification of family members to perform motor, cognitive and language stimulation activities is essential, as well as being available to request support and answer questions, including through social networks or by telephone.

In this study, the mothers showed that they acquire the ability to stimulate the child in their daily life in a pleasant and frequent manner, although concomitant with episodes of stiffness, agitation, sialorrhea and severe agitation, so as to associate the success of the treatment with their actions and their efforts. Thus, the meaning given to playing is resignified, and may be just a hobby or a way of learning and developing, favoring the socialization, cognitive and motor development of the child(18).

Interaction with groups of mothers was highlighted by the participants as an important support for them, the scientific literature shows as a protective aspect for the quality of family life ${ }^{(19)}$, from the sharing of experiences, the information seized on television or with health professionals who listen and act dialogically. Therefore, it is expected to achieve women's empowerment, encourage family self-care and parental participation by sharing the leading role of care.

Despite the relevance of their professional performance, other mothers report that only the interaction, "catching" and "feeling" their children ensures the best care for their children, disregarding the scientific knowledge used by professionals when compared to the knowledge and practices of family members ${ }^{(7)}$. Thus, the way women recognize the world and the social dynamics of women legitimize their knowledge and practices, in contrast to guidelines and routines planned by professionals who in asymmetrical power relations try to superimpose professional knowledge on family members.

Mothers say that health professionals have little regard for family subjectivities when orienting them about care ${ }^{(18)}$. The child may be at the moment irritable, crying, with severe stiffness and agitated, behaviors that the mother recognizes 
as the child's own will, so the time to establish care is not always the one recommended by the professionals ${ }^{(7)}$. In addition, health professionals tend to reinforce the naturalization of the maternal role, keeping the dialog only with the mothers, little questioning paternal care, contributing to the overload of maternal care ${ }^{(18)}$.

Discomforts are experienced by mothers due to excessive verbal guidance received from professionals, they recognize that some professionals do not have practices in care, which leads to discrediting information ${ }^{(7)}$. However, understanding congenital anomalies without professional support is complex and difficult, causing anxiety in family members. Therefore, when mothers come across news reported on television and the Internet, they turn to professionals for questions and confirmation of information ${ }^{(15)}$.

The scenario experienced by the mothers favors the imbalance of their health-disease process, so mothers take care of the child and get sick at the same time, while few studies investigate their care ${ }^{(13)}$. Among the health professions inherent in nursing is the performance of comprehensive and participatory practices of cared people, it makes use of bonding, communicative skills and scientific knowledge ${ }^{(20)}$ to achieve the most personal care. Thus, nursing is responsible for directing care interventions to mothers, maintaining continuous attention to reduce their vulnerability to illness.

\section{- CONCLUSIONS}

The experiences, knowledge and practices of family members of children with CZVS are unique and exceptional, built on the scenario of the epidemic, with inaccurate diagnosis and prognosis, participation in "mothers of micro" social groups and frequent relation with health professionals, consolidating a potent scenario for the exchange of knowledge and care practices. In children with CZVS, family members perform common care for children of the same age, plus early stimulation and playing for pedagogical purposes. However, this care is associated with involuntary movements, agitation, intense crying, muscle stiffness, airway obstruction, regurgitation and even convulsions, which require vigilance from mothers becoming singular, strenuous and tiring.

We identified the relevance of nursing professionals in the care of these families, which requires a horizontal relation, respecting their beliefs and culture of care, valuing their social role, helping to build intersections between popular and professional knowledge and active participation in therapeutic plans.
We advise the nursing staff to be vigilant regarding the technological innovations directed to the care of children with disabilities, use simple and objective language during contact with families, foster the identity construction of mothers to build their happiness projects, as well as participation of other family members in social groups. Due to the complex therapeutic itinerary and involvement of health professionals with specific behaviors, it is up to managers to qualify primary health care teams for better co-management of family care.

The participation of other family members in this study could reveal different experiences and care, broadening the theoretical body about the experience with CZVS, considering this a limitation of this manuscript that can be overcome with further studies.

\section{REFERENCES}

1. Araújo TVB, Rodrigues $L C$, Ximenes RAA, Miranda DB, Montarroyos UR, Melo APL, et al. Association between Zika virus infection and microcephaly in Brazil, January to May, 2016: preliminary report of a case-control study. Lancet Infect Dis. 2016;16(12):1356-63. doi: https://doi.org/10.1016/S14733099(16)30318-8

2. Campos MMMS, Sousa TC, Teixeira GP, Chaves KYS, Araújo MVUM, Sousa MR. Challenges and perspectives of mothers of children with microcephaly due to Zika virus infection. Rev Rene. 2018;19:e32839. doi: https://doi. org/10.15253/2175-6783.20181932839

3. Teixeira GA, Enders BC, Carvalho ALB, Dantas DNA, Carvalho GAFL, Silva AN. Análise do conceito síndrome congênita pelo Zika vírus. Cienc Saúde Coletiva. 2018 [cited 2019 Jul 19]. [Ahead of print]. Available from: http:// www.cienciaesaudecoletiva.com.br/artigos/analise-do-conceito-sindromecongenita-pelo-zika-virus $/ 16883 ?$ id $=16883$

4. Vigilância em saúde no Brasil 2003-2019: da criação da Secretaria de Vigilância em Saúde aos dias atuais. Bol Epidemiol. 2019 [cited 2019 0ct 18];50(n.esp.):1154. Available from: https://portalarquivos2.saude.gov.br/images/pdf/2019/ setembro/25/boletim-especial-21ago19-web.pdf

5. Vale PRLF, Cerqueira S, Santos HP, Black BP, Carvalho ESS. Bad news: families' experiences and feelings surrounding the diagnosis of Zika-related microcephaly. Nurs Inq. 2019;26:e12274. doi: https://doi.org/10.1111/ nin. 12274

6. Oliveira SJGS, Melo ES, Reinheimer DM, Gurgel RQ, Santos VS, Martins-Filho PRS. Anxiety, depression, and quality of life in mothers of newborns with microcephaly and presumed congenital Zika virus infection. Arch Womens Ment Health. 2016;19(6):1149-51. doi: https://doi.org/10.1007/s00737-0160654-0

7. Fleischer $S$. Segurar, caminhar e falar: notas etnográficas sobre a experiência de uma "mãe de micro" no Recife/PE. Cad Gênero Divers. 2017;3(2):93-112. doi: https://doi.org/10.9771/cgd.v3i2.21983 
8. Bailey Jr DB, Ventura LO. The likely impact of Congenital Zika Syndrome on families: considerations for family supports and services. Pediatrics. 2018;141(S.2):180-7. doi: https://doi.org/10.1542/peds.2017-2038G

9. Freitas PSS, Soares GB, Mocelin HJS, Lacerda LCX, Prado TN, Sales CMM, et al. Síndrome congênita do vírus Zika: perfil sociodemográfico das mães. Rev Panam Salud Publica. 2019;43(1):e24. doi: https://doi.org/10.26633/RPSP.2019.24

10. Minayo MCS. Amostragem e saturação em pesquisa qualitativa: consensos e controvérsias. Rev PesqQualit. 2017 [cited 2019jul 19];5(7):1-12. Available from: https://edisciplinas.usp.br/pluginfile.php/4111455/mod_resource/content/ 1/Minayosaturacao.pdf

11. Trinca W. Formas de investigação clínica em psicologia: procedimento de desenhos-estórias: procedimentos de desenhos de famílias com estórias. São Paulo: Vetor; 1997

12. Braun V, Clarke V. Using thematic analysis in psychology. Qual Res Psychol. 2006;3(2):77-101. https://doi.org/10.1191/1478088706qp0630a

13. Santos DSS, Mercês MO, Souza RL, Santana AL. Cuidados à criança com Síndrome Congênita do Zika: revisão sistemática. Rev Bras Saúde Funcional. 2018 [cited 2019 Jul 10];6(1):81-92. Disponível em: http://www.seer-adventista.com.br/ ojs/index.php/RBSF/article/view/1015

14. Lopez-Camelo JS, Orioli IM, Castilla E. Documento ECLAMC final: resumo e conclusões dos documentos 1-5. Buenos Aires: ECLAMC, 2015 [cited 2019 Jul 10]. v. 3. Available from: http://www.eclamc.org/descargas/6. DocumentoECLAMCFinalV3.docX
15. Sá FE, Andrade MMG, Nogueira EMC, Lopes JSM, Silva APEP, Assis AMV. Parental needs in the care for children with zika virus-induced microcephaly. Rev Bras Promoç.Saúde. 2017;30(4).doi: https://doi.org/10.5020/18061230.2017.6629

16. Scott RP, Lira LC, Matos SS, Souza FM, Silva ACR, Quadros MT. Therapeutic paths, care and assistance in the construction of ideas about maternity and childhood in the context of the Zika virus. Interface (Botucatu). 2018;22(66):673-84. doi: https://doi.org/10.1590/1807-57622017.0425

17. Brunoni D, Blascovi-Assis SM, Osório AAC, Seabra AG, Amato CAH, Teixeira MCT, et al. Microcephaly and other Zika virus related events: the impact on children, families and health teams. Ciênc Saúde Coletiva. 2016;21(10):3297-302. doi: https://doi.org/10.1590/1413-812320152110.16832016

18. Bustamante V, McCallum CA. Caring for pregnant women and babies in the context of the Family Healthcare Program: an ethnographic study. Interface (Botucatu). 2010;14(34):607-18. doi: https://doi.org/10.1590/\$1414-328320 10005000011

19. Vuorenmaa M, Halme N, Perälä ML, Kaunonen M, Astedt-Kurki P. Perceived influence, decision-making and access to information in family services as factors of parental empowerment: a cross-sectional study of parents with young children. Scand J Caring Sci. 2016;30(2):290-302. doi: https://doi. org/10.1111/scs. 12243

20. Gomes TEB, Ivo OP. Sistematização da assistência de Enfermagem em mulheres com sintomatologia depressiva: uma revisão sistemática. Id on Line Rev Mult Psic. 2017 [cited 2019 Jul 10];11(38):835-48. Available from: https://idonline. emnuvens.com.br/id/article/view/957/1359h

\section{- Corresponding author:}

Paulo Roberto Lima Falcão do Vale

E-mail: paulofalcaovale@ufrb.edu.br

\section{Associate editor:}

Rosana Maffacciolli 